\title{
HISTÓRIA E DIVERSIDADE: POLITICA, EDUCAÇÃO, GÊNERO E ETNIA EM RORAIMA
}

\author{
Maria Luiza Fernandes* e Manoel Luiz Lima Salgado Guimarães** (Org.) \\ Boa Vista, RR: EdUFRR, 2010. 300 p. ISBN : 978-85-602-1558-4 \\ Responsável pela resenha: Maria Edith Romano Siems***
}

\section{O livro intitulado História e Diversidade: Política, Educação, Gênero e Etnia em} Roraima, lançado pela editora da Universidade Federal de Roraima no ano de 2010, destina-se a leitores e pesquisadores que se interessam e veem-se envolvidos em estudos da historiografia brasileira e que se sintam instigados a aprofundar conhecimentos na diversidade regional de nosso país, que, por sua dimensão continental, apresenta nuances tão complexas em sua constituição histórica e cultural.

Este livro apresenta os resultados de um programa de qualificação de pessoal docente, apoiado pela Capes e desenvolvido de forma integrada pela Universidade Federal do Rio de Janeiro e pela Universidade Federal de Roraima no período de 2001 a 2003. Esse programa resultou na concretização de 10 dissertações enfocando as temáticas educação, gênero e questão indígena, que, desenvolvidas sob a ótica de sua constituição histórica no Estado de Roraima, apresentam um rico painel para o aprofundamento de estudos acerca desse que é o Estado mais setentrional do Brasil.

O principal objetivo da obra é apresentar os resultados dessa produção, profícua para ambas as instituições participantes, já que, ao integrar professores e pesquisadores residentes no Estado de Roraima a um conjunto de pesquisadores cujo foco de observação está posto no centro-sul do país, oportuniza um alargamento de horizontes no desenvolvimento do fazer historiográfico. Conforme destacam os organizadores do livro em sua apresentação, "o descentramento de um projeto desta natureza contribui para repensar os quadros da produção historiográfica feita em nosso país e pode em muito contribuir para interrogarmos os princípios a partir dos quais se escreveu e se escreve a história nacional".

* Doutora em História Social pela Universidade de São Paulo, Brasil (2000). Professora Associado 1 da Universidade Federal de Roraima (UFRR). Editora da revista Textos e Debates (UFRR) (mluizaf@ technet.com.br).

** Doutor em História pelo Freie Universität Berlin, Alemanha (1987). Pós-Doutor pela École des Hautes Études en Sciences Sociales, França (2000). Ex-Professor Adjunto da Universidade Federal do Rio de Janeiro, Brasil. Ex-Presidente da Associação Nacional de História (Rio de Janeiro, 16 fev. 1952 - 27 abr. 2010).

*** Doutoranda em Educação Especial na Universidade Federal de São Carlos, SP, Brasil. Mestra em Educação pela Universidade Federal de Juiz de Fora, Brasil (2008). Professora Assistente da Universidade Federal de Roraima, Boa Vista - RR (msiems@uol.com.br). 
O livro está dividido em 10 capítulos, organizados em três grandes blocos temáticos: questão indígena, gênero e educação. Rompendo, no entanto, com a perspectiva tradicional de organização desse tipo de obra, de apresentar resumos das dissertações produzidas, o livro oportuniza aos leitores o acesso a um capítulo de cada uma das dissertações produzidas. Esses capítulos foram selecionados e lapidados por seus próprios autores por sua expressividade no conjunto da obra e considerando sua relevância para a historiografia regional.

No primeiro eixo, que toma por foco a questão indígena, encontramos a maior concentração da produção apresentada - sete capítulos -, fato natural se considerado o expressivo contingente dessas populações no Estado de Roraima e a emergência das discussões relacionadas à demarcação das terras indígenas do Estado ao tempo de sua produção. São estudos que, passando por grupos de etnias diversas, com destaque para os Yanomamis e Macuxis, apresentam aspectos que vão da construção da imagem do indígena por missionários norte-americanos na segunda metade do século XX, à política indigenista desenvolvida pelo SPI - Serviço de Proteção aos Índios na primeira metade do século XX, com destaque para o processo histórico de organização dos povos indígenas no Estado de Roraima. Nesta temática, encontramos ainda estudos acerca de aspectos culturais e políticos que envolvem a presença de indígenas nas áreas urbanas e o processo de reconhecimento dos indígenas como sujeitos de direito na Constituição brasileira.

No eixo cujo foco central é o viés de gênero, vemos ainda a interlocução com a questão indígena, onde se registra o processo de organização das mulheres indígenas em Roraima que culminou na criação da Omir - Organização das Mulheres Indígenas de Roraima. Encontramos ainda um trabalho peculiar acerca do processo migratório vivenciado no Estado por mulheres oriundas da região nordeste, que, no extremo norte do país, "reinventaram" suas vidas e se constituiram como sujeito mulher.

A última temática enfocada refere-se a estudos no campo da educação, área em que a historiografia regional ainda apresenta lacunas expressivas. Nesse sentido, vamos encontrar um texto que registra o impacto de políticas nacionais de educação no "Território Federal do Rio Branco no período 19461951" e outro que apresenta o histórico da implantação da educação profissionalizante e da transformação da Escola Técnica Estadual em Escola Técnica Federal no então Território Federal de Roraima.

Trata-se de uma obra de grande relevância para todos os que pretendem a ampliação da compreensão da constituição histórica de nosso país, que, em suas dimensões continentais, apresenta uma riqueza e uma diversidade ímpares. Como destacam os organizadores desta obra: "ler o diferente pode também contribuir para que nos conheçamos melhor, alargando os horizontes do fazer historiográfico". 